\title{
大腦皮質組織の呼吸に及ぼす抗㾏孚剤の 作用機転に就
}

\author{
医学上佐々 木友行 \\ (京都府立医科大学薬理学教室〔主任 小沢教授】)

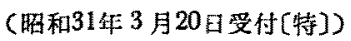

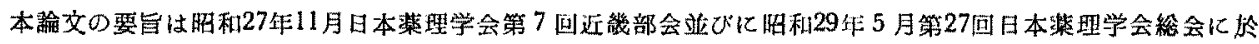
て発売した。

\begin{abstract}
第1章 緹
$\overline{\underline{ \pm}}$

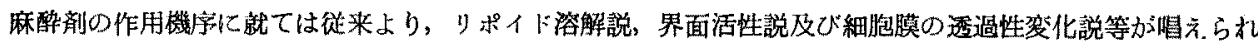

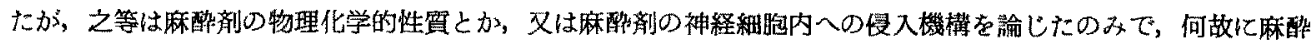

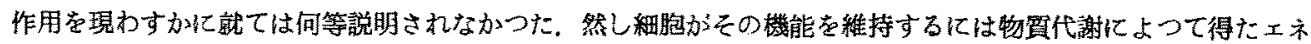

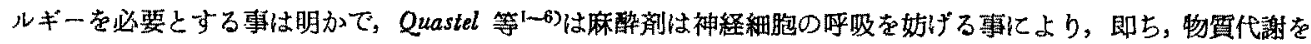

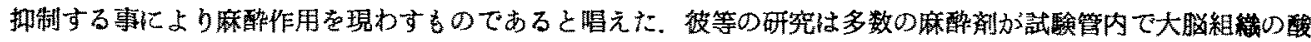

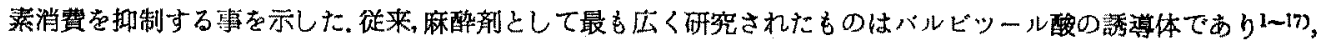

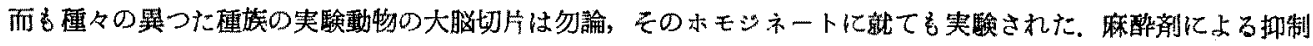

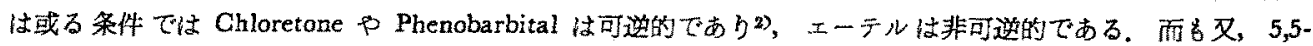
Dipropyl-2,4-oxazolidine-dione $と$ 5,5-Diphenyl-2,4-oxazolidine-dione の間にさえ方可逆件に於て相堂があり，

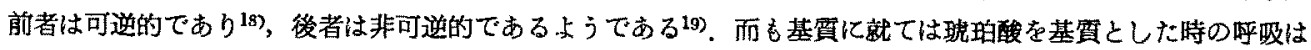

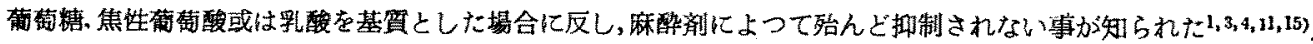

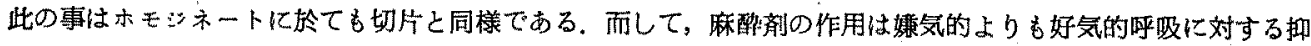

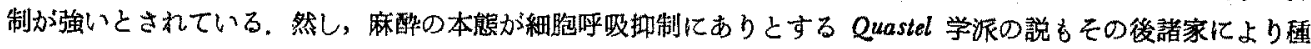

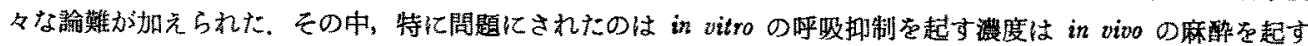

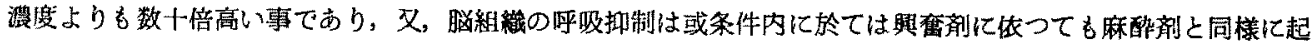

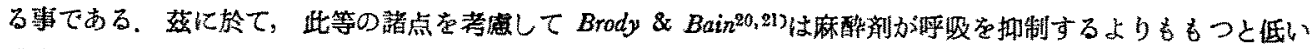

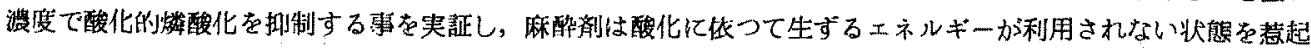

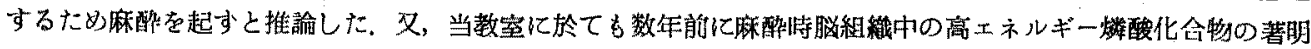

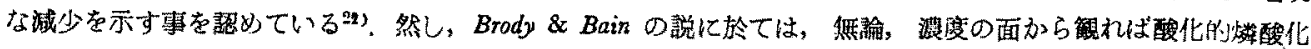

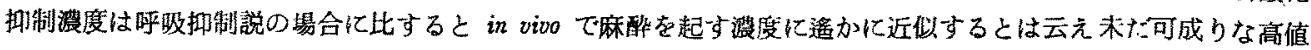

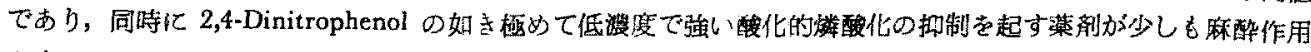
を有しない事实志説明する椠が山来ない憾がある。

以上の如くQuastel 学派の説は麻醉作用の本態に触れた重要な一面支表してはいるが，末た完全に解決され ない状態である。

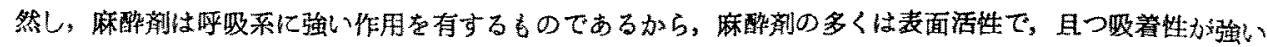

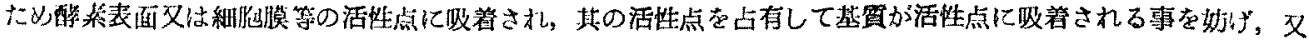


は活性点を構成する要菜を破挍して紐胞機能の低下を招来するものであると解説している学者もある。.

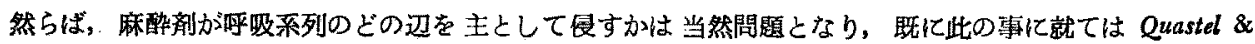

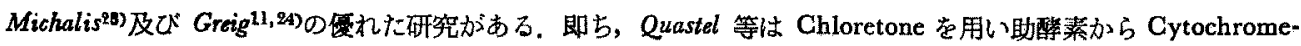

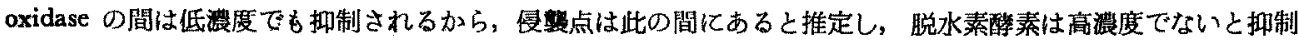
されないと報告し，Greig は Flavoprotein と Cytochrome c と連絡するビタミンCにより Pentobarbital の 抑制が除かれるから唚敦点は此の二つの酥菜の間にあると推定している.

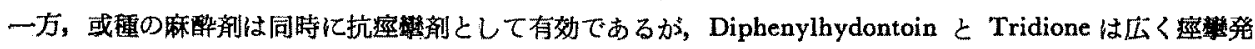
作の治療に用いられ，特に前者恃大発作仁，後者は小発作に使用されるが，其の薬理学的作用は必ずしも麻醉剂

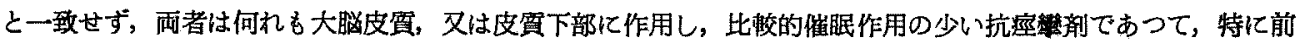
者は抗座算作用は Phenobarbital と相似なるも，催腿作用を㱠んど有しないるのである，従つて此の両作用は各

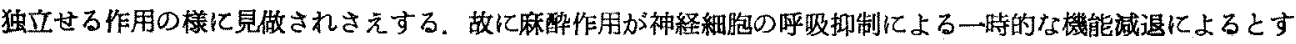

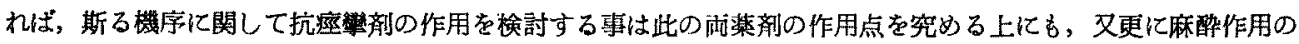

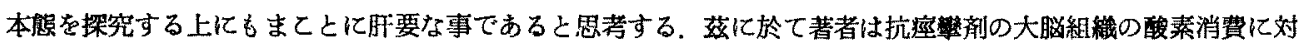

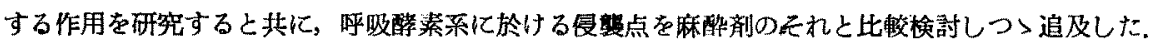

\section{第 2 草 実 験 方 法}

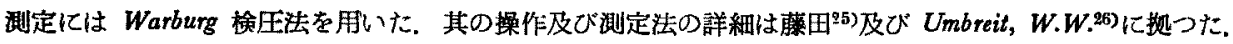

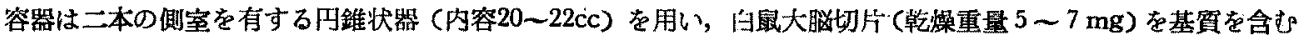

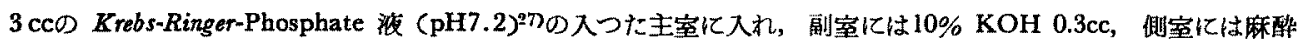

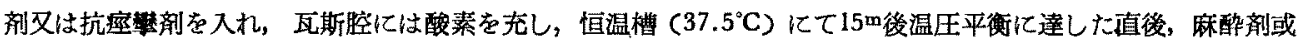

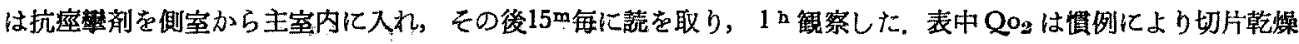

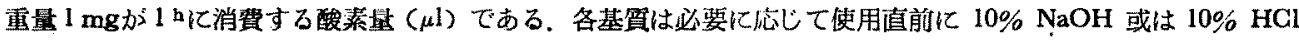
でH7.2に調整した。

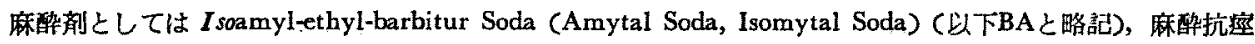

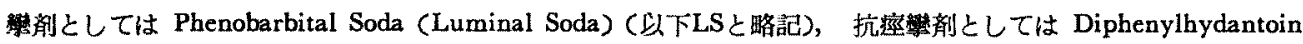
Natorium (Aleviatin) (以下ALと略記) 及び 3,3,5-Trimethyl-oxazolidine-2,4-dione (Tridione, Minoaleviatin)

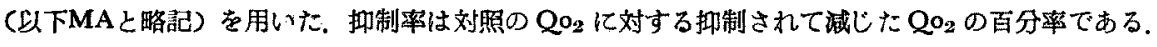

嫌気性実験方法や醭素系に於ける実䣲方法は各々の処で述べる。

\section{第3章 実 驗 成 箖

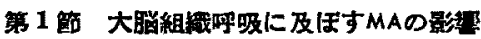

第1表。各種基賈に於ける白鼠大脳組機呼吸に及ぼすMAの影響。

\begin{tabular}{|c|c|c|c|c|c|c|c|c|c|c|c|c|}
\hline \multirow{3}{*}{ 基 } & \multirow{3}{*}{ 基䨢溊度 } & \multirow{2}{*}{ 䇅 } & \multirow{2}{*}{ 照 } & \multicolumn{3}{|r|}{$\mathbf{M}$} & \multicolumn{2}{|l|}{ A } & 浀 & \multicolumn{2}{|c|}{ 理 } & \\
\hline & & & & \multicolumn{3}{|c|}{$1 \times 10^{-2} \mathrm{M}$} & \multicolumn{3}{|c|}{$5 \times 10^{-2} \mathrm{M}$} & \multicolumn{3}{|c|}{$1 \times 10^{-1} \mathrm{M}$} \\
\hline & & 例数 & $\mathrm{QO}_{2}$ & 例数 & $Q_{2}$ & $\mid \begin{array}{c}\text { 抑制率 } \\
(\%)\end{array}$ & 例数 & $\mathrm{Qo}_{2}$ & $\begin{array}{c}\text { 却制率 } \\
(\%)\end{array}$ & 例数 & $\mathrm{QO}_{2}$ & $\mid \begin{array}{c}\mid \begin{array}{l}\mid \\
(\%)\end{array} \\
\end{array}$ \\
\hline 菊荡榶 & $0.02 \mathrm{M}$ & 5 & 14.7 & 5 & 13.8 & 6.1 & 5 & 11.8 & 19.7 & 5 & 7.5 & 48.6 \\
\hline 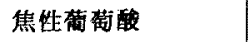 & $0.02 \mathrm{M}$ & 5 & 12.7 & 5 & 12.2 & 3.9 & 5 & 11.8 & 11.0 & 5 & 7.3 & 36.9 \\
\hline 苳酩酸 & $0.03 \mathrm{M}$ & 5 & 11.5 & - & - & - & - & - & - & 5 & 6.1 & 46.6 \\
\hline $\boldsymbol{\alpha} \boldsymbol{\alpha}$ ケトグルタール酸 & $0.02 \mathrm{M}$ & 5 & 7.9 & - & - & - & - & - & - & 5 & 5.4 & 31.1 \\
\hline 构端酸 & $.0,02 \mathrm{M}$ & 5 & 3.8 & - & - & - & - & - & - & 5 & 2.6 & 31.6 \\
\hline 琥珀酸 & $0.02 \mathrm{M}$ & 5 & 9.9 & - & - & - & - & - & - & 5 & 8.2 & 17.6 \\
\hline 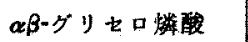 & $0.02 \mathrm{M}$ & 5 & 7.7 & - & - & - & - & - & - & 5 & 6.7 & 14.2 \\
\hline$p$-Phenylendiamin & $2.5 \mathrm{mM}$ & 5 & 9.5 & - & - & - & - & - & - & 5 & 8.5 & 11.0 \\
\hline
\end{tabular}




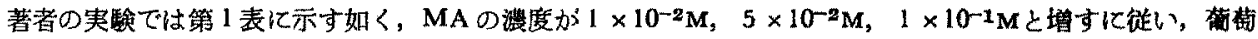

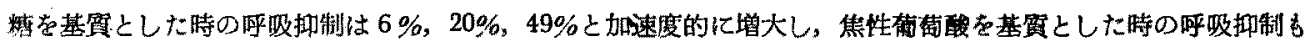

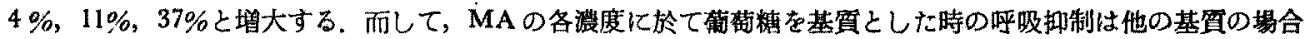

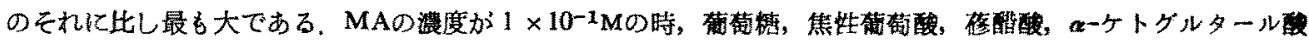

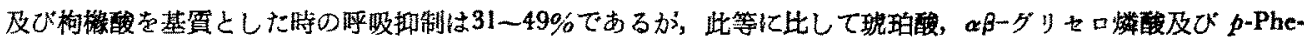

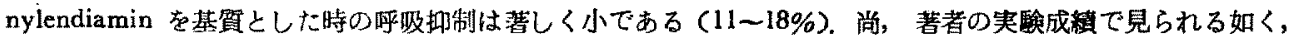

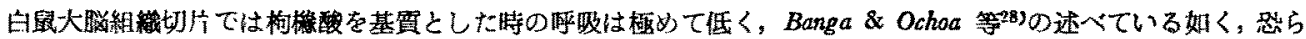
く睬組緎では枸藉酸は利用されない様である。

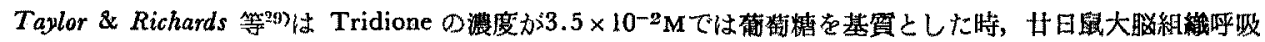

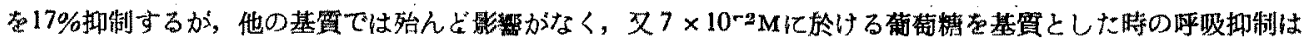
Methylen blue (以下Mb之略記) に上り大部分回復すると報告している。

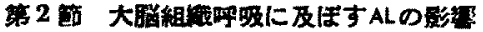

ALは使用直前に $10 \% \mathrm{HCl}$ でpH7.2にて補正したが，此のpHに於ては使用した漶度では幾分白濁する様であ

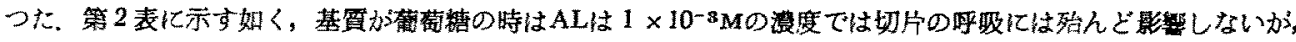

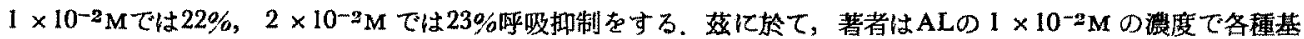

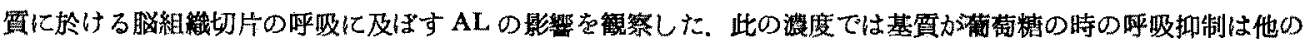

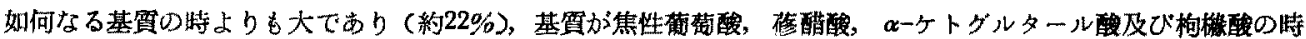

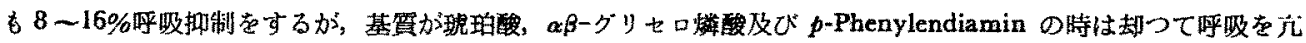
進する傾向を示した $(3 \sim 7 \%)$.

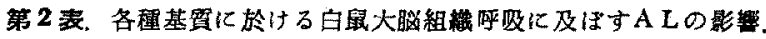

\begin{tabular}{|c|c|c|c|c|c|c|c|c|c|c|c|c|}
\hline \multirow{3}{*}{ 基 } & \multirow{3}{*}{ 基䁈灌周 } & \multirow{2}{*}{ 対 } & \multirow{2}{*}{ 照 } & \multicolumn{3}{|r|}{ A } & \multicolumn{2}{|l|}{ L } & 瀼 & \multicolumn{2}{|c|}{ 度 } & \\
\hline & & & & \multicolumn{3}{|c|}{$1 \times 10^{-3} \mathrm{M}$} & \multicolumn{3}{|c|}{$1 \times 10^{-2} \mathrm{M}$} & \multicolumn{3}{|c|}{$2 \times 10^{-2} \mathrm{M}$} \\
\hline & & 例数 & $\mathrm{QO}_{2}$ & 例数 & $\mathrm{QO}_{2}$ & $\begin{array}{c}(\%) \\
(\%)\end{array}$ & 例数 & $\mathrm{Qo}_{2}$ & $\begin{array}{c}\text { 牞制率 } \\
(\%)\end{array}$ & 例数 & $Q o_{3}$ & $\begin{array}{l}\text { 制事 } \\
(\%)\end{array}$ \\
\hline 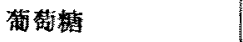 & $0.02 \mathrm{M}$ & 5 & 15.0 & 5 & 14.9 & 0.7 & 5 & 11.8 & 22.0 & 5 & 11.5 & 23.3 \\
\hline 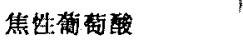 & $0.02 \mathrm{M}$ & 5 & 11.6 & 5 & 11.6 & 0 & 5 & 10.6 & 8.1 & 5 & 10.6 & 8.6 \\
\hline 落醌酸 & $0.03 \mathrm{M}$ & 5 & 13.0 & - & - & - & 5 & 11.8 & 9.1 & - & - & - \\
\hline а-ケトグルタール酸 & $0.02 \mathrm{M}$ & 5 & 7.9 & - & - & - & 5 & 6.6 & 16.5 & - & - & - \\
\hline 构筑韵 & $0.02 \mathrm{M}$ & 5 & 3.5 & - & - & - & 5 & 3.1 & 11.4 & - & -- & - \\
\hline 琥珀酸 & $0.02 \mathrm{M}$ & 5 & 10.3 & - & - & - & $\cdot 5$ & 10.6 & -2.9 & - & - & - \\
\hline$\alpha \beta-タ ゙ リ 七$ 口懽酸 & $0.02 \mathrm{M}$ & 5 & 7.2 & - & - & - & 5 & 8.1 & -6.8 & - & - & - \\
\hline$p$-Phenylendiamin & $2.5 \mathrm{~mm}$ & 5 & 8.4 & - & - & - & 5 & 8.8 & -3.0 & - & - & - \\
\hline
\end{tabular}

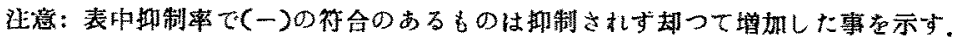

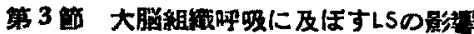

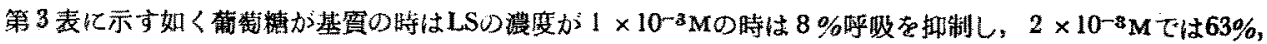

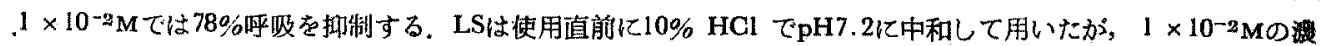

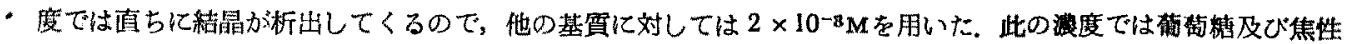

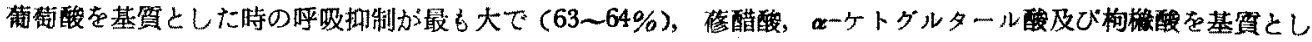

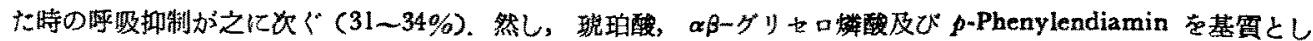
だ時の㭔吸抑制恃非常に小である $(5 \sim 15 \%)$.

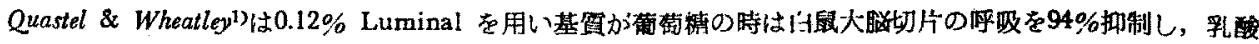

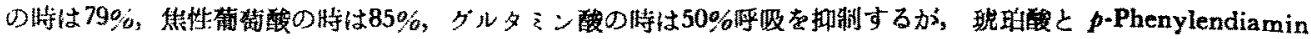




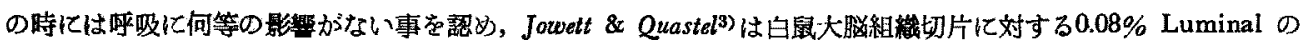

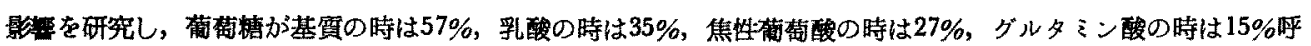
眨抑制をするが，琥珀酸の時には却つて $7 \%$ 呼吸の元進を稳めている。

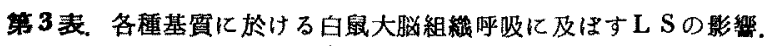

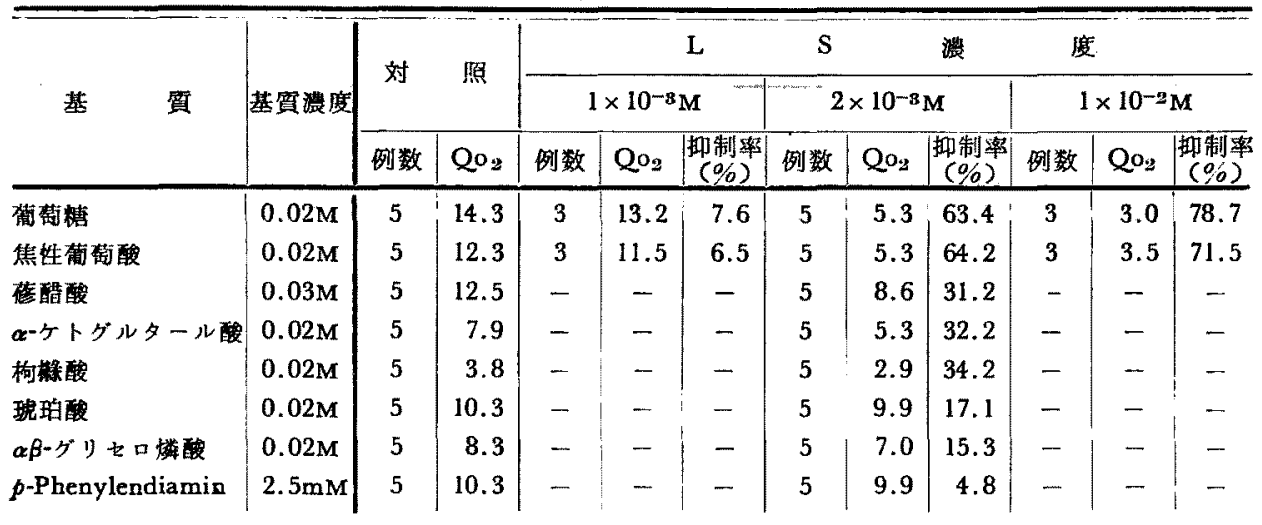

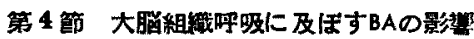

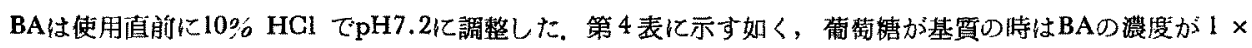

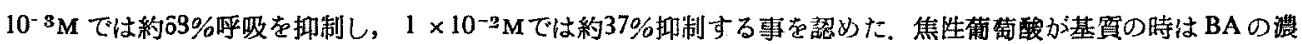

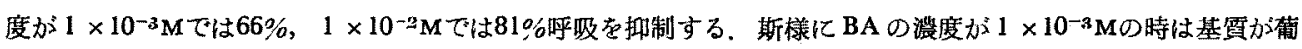

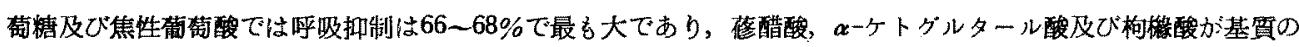

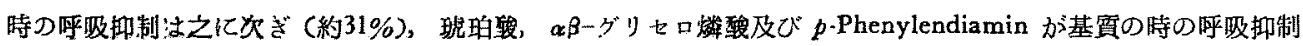
は非常に小さい $(7 \sim 15 \%)$. Wortis ${ }^{30)}$ を Amytal は武験管内で大脳切片の呼吸を抑制する事を認めている。

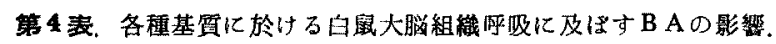

\begin{tabular}{|c|c|c|c|c|c|c|c|c|c|}
\hline \multirow{3}{*}{ 基 } & \multirow{3}{*}{ 基留濃度 } & \multirow{2}{*}{ 対 } & \multirow{2}{*}{ 照 } & & B & A & \multicolumn{3}{|c|}{ 度 } \\
\hline & & & & \multicolumn{3}{|c|}{$1 \times 10^{-8} \mathrm{M}$} & \multicolumn{3}{|c|}{$1 \times 10^{-2} \mathrm{M}$} \\
\hline & & 例 数 & $Q_{0.2}$ & 例 数 & $\mathrm{QO}_{\mathrm{i}}$ & $\begin{array}{c}\text { 却制率 } \\
(\%)\end{array}$ & 例 数 & Q०:2 & $\begin{array}{c}\text { 㧕制率 } \\
(\%)\end{array}$ \\
\hline 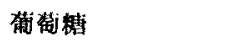 & $0.02 \mathrm{M}$ & 5 & 15.6 & 5 & 5.0 & 67.9 & 3 & 2.0 & 87.2 \\
\hline 焦制雨衔酸 & $0.02 \mathrm{M}$ & 5 & 13.7 & 5 & 4.6 & 66.4 & 3 & 2.6 & 81.0 \\
\hline 莿醋酸 & $0.03 \mathrm{M}$ & 5 & 13.7 & 5 & 9.4 & 31.4 & - & - & - \\
\hline$\alpha$-ケトグルタール酸 & $0.02 \mathrm{M}$ & 5 & 6.4 & 5 & 4.4 & 31.3 & - & - & - \\
\hline 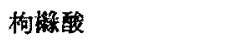 & $0.02 \mathrm{M}$ & 5 & 3.8 & 5 & 2.6 & 31.6 & - & - & - \\
\hline 琥珀酸 & $0.02 \mathrm{M}$ & 5 & 10.1 & 5 & 8.8 & 12.9 & - & - & - \\
\hline$\alpha \beta-ク ゙ り セ \square$ 燐酸 & $0.02 \mathrm{M}$ & 5 & 7.3 & 5 & 6.2 & 15.1 & - & - & - \\
\hline$p$-Phenylendiamin & $2.5 \mathrm{mM}$ & 5 & 9.5 & 5 & 8.8 & 7.4 & - & - & - \\
\hline
\end{tabular}

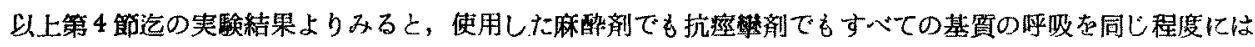

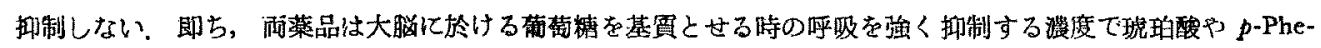
nylendiamin を基筫とした時の呼吸を殆んど抑制しない，従つて此の成繢よりすると，呼吸過程に関する限りで

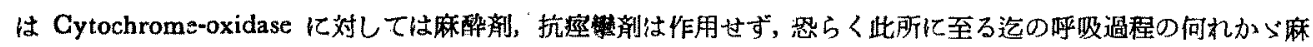

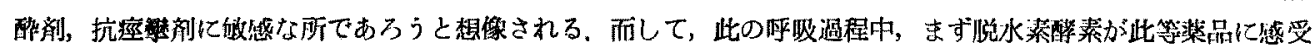




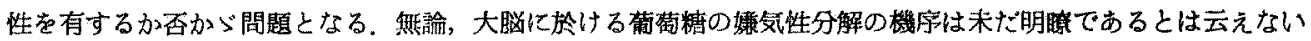

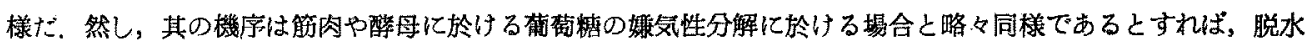

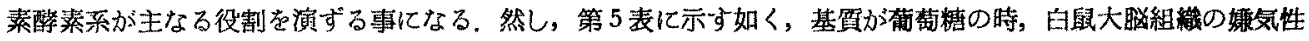

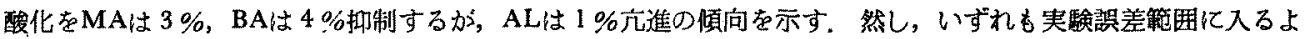

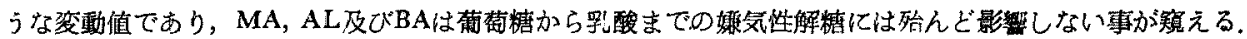

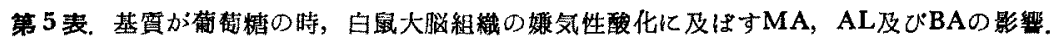

\begin{tabular}{|c|c|c|c|c|c|c|c|c|c|c|}
\hline 対 & \multirow{2}{*}{$\frac{\text { 觜 }}{Q_{M}^{N_{2}}}$} & \multicolumn{3}{|c|}{$\begin{array}{c}\mathrm{MA} \\
\left(1 \times 10^{-1} \mathrm{M}\right)\end{array}$} & \multicolumn{3}{|c|}{$\left(1 \times 10^{-2} \mathrm{M}\right)$} & \multicolumn{3}{|c|}{$\left(1 \times 10^{-3} \mathrm{M}\right)$} \\
\hline 例 数 & & 例 数 & $Q_{M^{2}}^{N_{2}}$ & $\begin{array}{l}\text { 㧕制率 } \\
(\%)\end{array}$ & 例 数 & $Q_{M_{2}}^{N_{2}}$ & $\begin{array}{c}\text { 㧕制率 } \\
(\%)\end{array}$ & 例 数 & $Q_{M}^{N_{y}}$ & $\begin{array}{l}\text { 婂制率 } \\
(\%)\end{array}$ \\
\hline 3 & 13.5 & 3 & 13.1 & 2.9 & 3 & 13.6 & -0.7 & 3 & 13.0 & 3.7 \\
\hline
\end{tabular}

注意：表中㧕制率て(一)の符合のあるるのは抑制されず，却つて增加した事る示す。

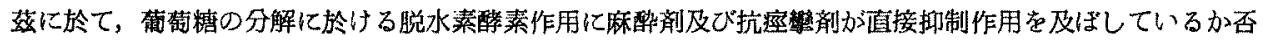
がー关明らかにするためと炏の実験を行つた。

\section{第 5 節 赤血醏法による実糇}

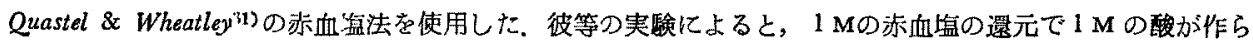

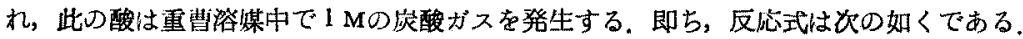

$$
\begin{aligned}
& \mathrm{H}+\mathrm{Fe}(\mathrm{CN}) \mathrm{a}^{\prime \prime \prime} \longrightarrow \mathrm{H}^{+}+\mathrm{Fe}(\mathrm{CN})_{\mathrm{a}}^{\prime \prime \prime \prime} \\
& \mathrm{H}^{+}+\mathrm{HCO}_{3} \stackrel{\longrightarrow}{\longrightarrow} \rightarrow \mathrm{H}_{2} \mathrm{CO}_{3} \longrightarrow \mathrm{CO}_{2}+\mathrm{H}_{2} \mathrm{O}
\end{aligned}
$$

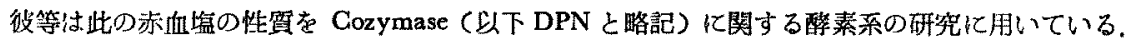

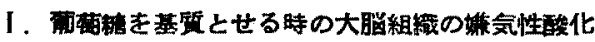

測定には Warburg 検圧法点用 いた. Ringer 液の組成仕 $\mathrm{NaHCO}_{3}$ $0.025 \mathrm{M}, \mathrm{KCl} 0.006 \mathrm{M}, \mathrm{CaCl}_{2} 0.001$ $\mathrm{M}, \mathrm{NaCl} 0.13 \mathrm{M}(\mathrm{pH} 7.3)$ で, 赤血 㙁液の組成は $5 \mathrm{cc} \oslash 10 \% \mathrm{Na}_{8} \mathrm{Fe}$ $(\mathrm{CN})_{e}$ と $1 \mathrm{cc} \oplus 0.16 \mathrm{M}-\mathrm{NaHCO}_{3}$ と よりなる。瓦斯腔には $5 \% \mathrm{CO}_{2}+95$

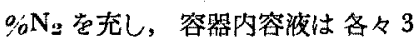

\begin{tabular}{|c|c|c|c|c|c|}
\hline \multirow{2}{*}{ 基 } & \multicolumn{2}{|l|}{ 対 } & \multicolumn{3}{|c|}{ 赤血㙋添加 } \\
\hline & 例 数 & $Q_{C O}^{N_{2}}$ & 例 数 & $Q_{\stackrel{\mathrm{CO}_{2}}{\mathrm{~N}_{2}}}$ & $\begin{array}{c}\text { 増加率 } \\
(\%)\end{array}$ \\
\hline- & 3 & 1.2 & 3 & 1.9 & - \\
\hline 葡䡈糖 $(0.02 \mathrm{M})$ & 3 & 13.6 & 3 & 18.1 & 33.1 \\
\hline 焦生策匍酸 $(0.02 \mathrm{M})$ & 3 & 3.1 & 3 & 4.6 & 48.4 \\
\hline
\end{tabular}

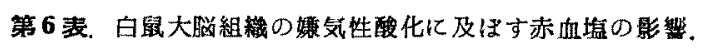

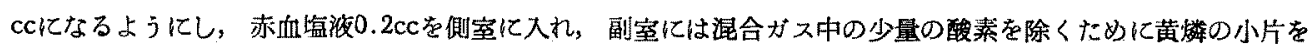

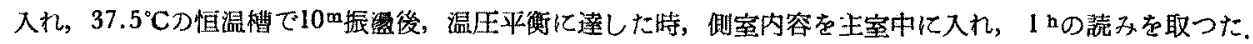

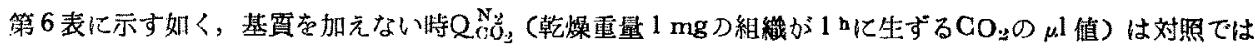

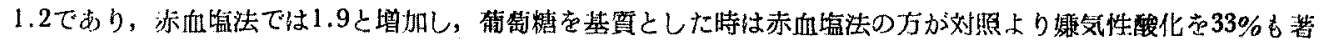

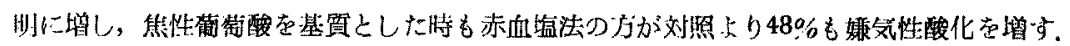

\section{1. 䗇気性酸化に及ぼすMA，AL及びBAの影譩}

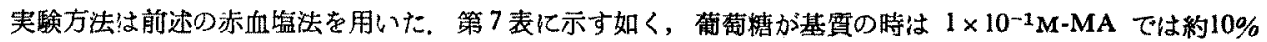

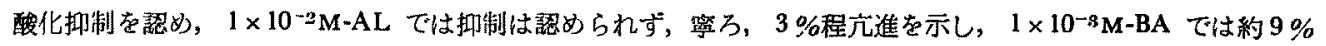

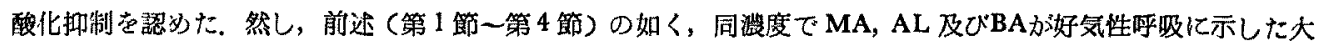

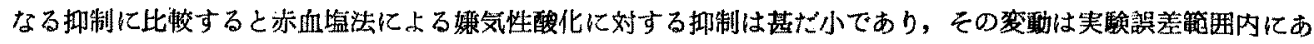
るとも云える，それ故，葡萄糖の存在下に白鼠大脪組織による赤血塭の退元に主要なる役割をしている脱水素醉

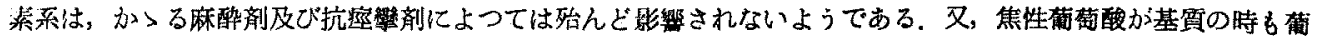

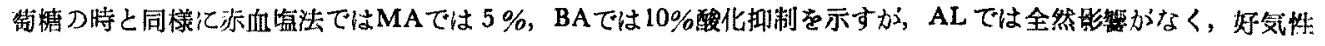

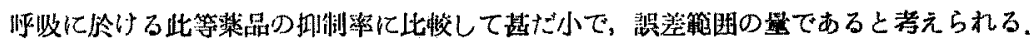




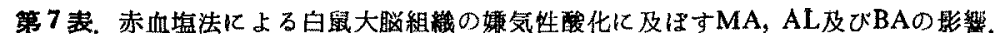

\begin{tabular}{|c|c|c|c|c|c|c|c|c|c|c|c|}
\hline \multirow{2}{*}{ 基 } & \multicolumn{2}{|l|}{ 詨 } & \multicolumn{3}{|c|}{$\left(\begin{array}{c}\mathrm{MA} \\
\left(1 \times 10^{-1} \mathrm{M}\right)\end{array}\right.$} & \multicolumn{3}{|c|}{$\left(\begin{array}{c}\mathrm{AL} \\
\left(1 \times 10^{-2} \mathrm{M}\right)\end{array}\right.$} & \multicolumn{3}{|c|}{$\left(\begin{array}{c}\text { BA } \\
\left(1 \times 10^{-8} M\right)\end{array}\right.$} \\
\hline & 例数 & $Q_{\mathrm{CO}_{2}}^{\mathrm{N}_{2}}$ & 例数 & $\mathrm{Q}_{\mathrm{CO}_{2}}^{\mathrm{N}_{2}}$ & \begin{tabular}{|l|}
$(\%)$ \\
$(\%)$
\end{tabular} & 例数 & $Q_{\mathrm{CO}}^{\mathrm{N}}$ & 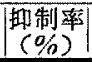 & 例数 & $Q_{C_{2}}^{N O_{2}}$ & $\begin{array}{l}\text { 抑制率 } \\
(\%)\end{array}$ \\
\hline 笨喵楉(0.02M) & 5 & 18.4 & 5 & 16.6 & 9.8 & 5 & 18.9 & -2.7 & 5 & 16.8 & 8.7 \\
\hline 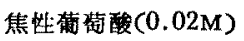 & 5 & 4.0 & 5 & 3.8 & 5.0 & 5 & 4.0 & 0 & 5 & 3.6 & 10.0 \\
\hline
\end{tabular}

注意：表中抑制率で(一)の符合のあるものは抑制されず，却つて增加する事を示す。

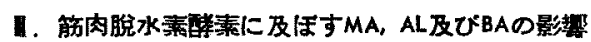

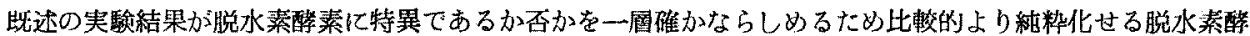

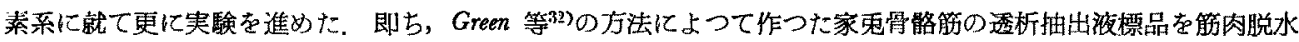

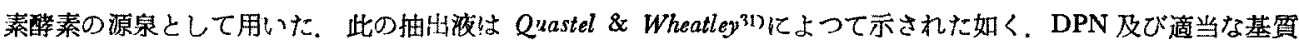

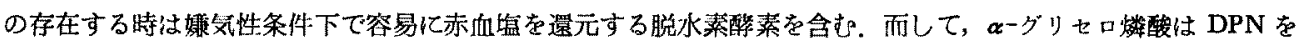

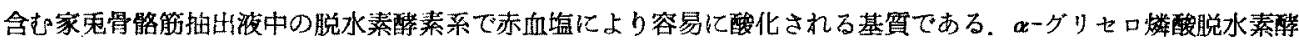
素には Green ${ }^{33)}$ の発見にか〉る Cytochrome を受容体とし，DPNゃ Flavoprotein 存要としない Cytochrome

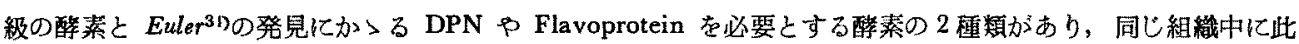

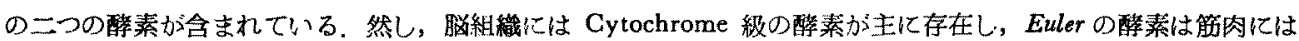

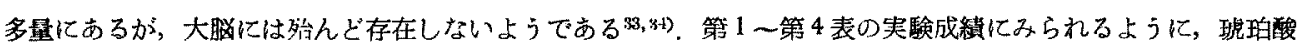

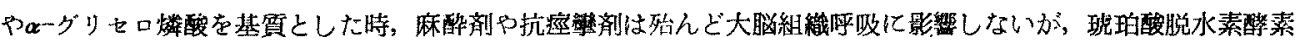

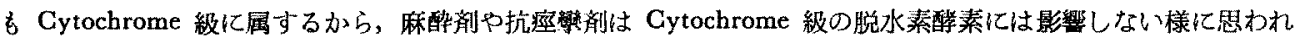

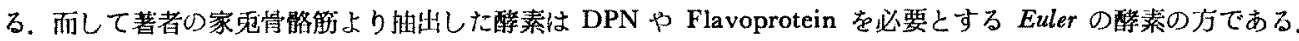

DPN は Oriental yeast より Williamson 氏法 ${ }^{3 \mathfrak{3})}$ と作つた.

此の作られた 2 喠の粠素の効力を知るだめに次の奏験を行つた.

容器内容液は $3 \mathrm{cc}$, 声公には 0.1

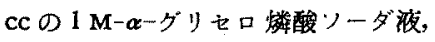
$0.2 \mathrm{cc}$ ○赤血塩一重曹液，Ringer 氏波 (組成は本節 I と同様), 側室には $1 \mathrm{cc}$ の筋肉抽出液, 他方の僛室には1 mg DPN を入れ， $\mathrm{pH} 7.3$, 副室に借黄燐の 小片を入れ，ガス腔には $5 \% \mathrm{CO}_{2}+95$ $0 \mathrm{~N}_{2}$ を充し, $38^{\circ} \mathrm{C}$ ○恒温槽にて $7 \mathrm{~m}$ 後, 温王平衡に迲した特, 側室内容を

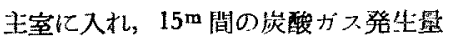
をみた。

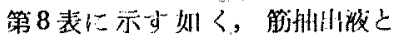
DPN 或は基筫と筋抽出腹を久くと最

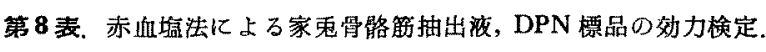

\begin{tabular}{|c|c|c|}
\hline & 例数 & 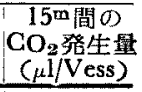 \\
\hline$\alpha-ク ゙$ り口粼酸十筋抽出液 & 3 & 13 \\
\hline DPN＋筋抽出紧 & 3 & 22 \\
\hline 節抽出液十赤血塩 & 3 & 31 \\
\hline 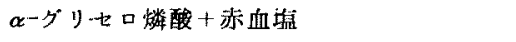 & 3 & 0 \\
\hline DPN十赤血筒 & 3 & 0 \\
\hline 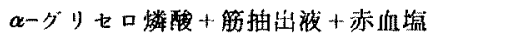 & 3 & 40 \\
\hline 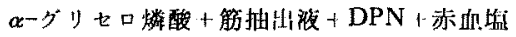 & 3 & 164 \\
\hline
\end{tabular}

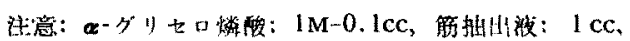
DPN: $1 \mathrm{mg}$, 胁血鼠没: $0.2 \mathrm{cc}$.

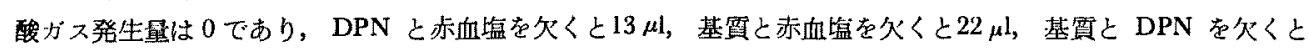
$31 \mu \mathrm{l}, \mathrm{DPN}$ のみ炎くと $40 \mu \mathrm{I}$ であるが，完全系では $164 \mu \mathrm{l}$ と著しく背進する。

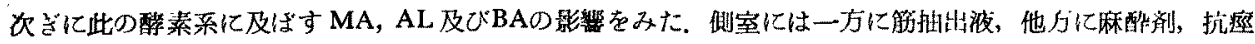

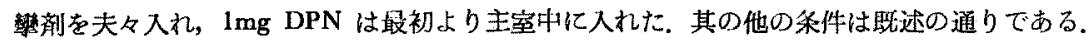

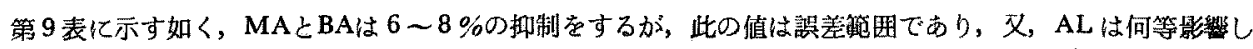

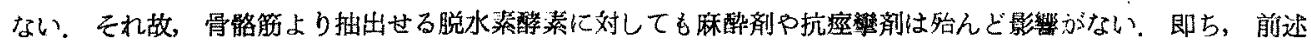
(本節】) の自鼠大脳組織の時と同様である.

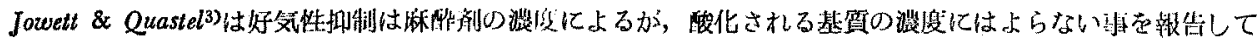




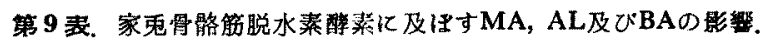

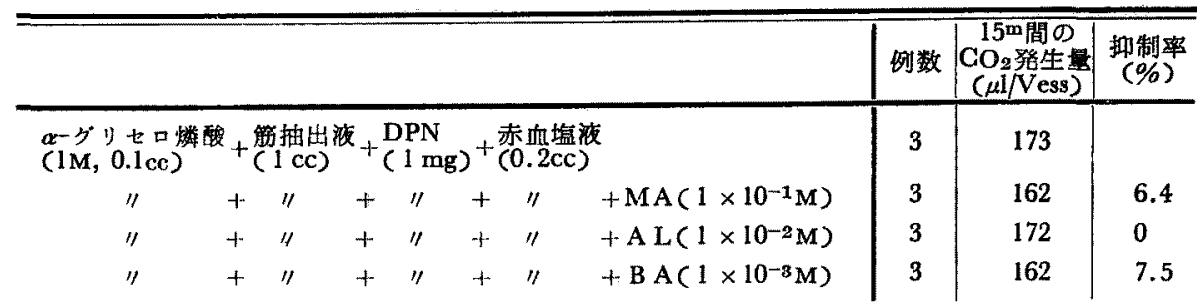

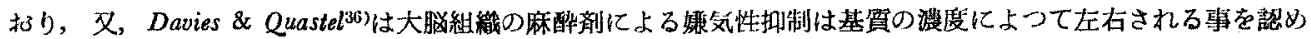

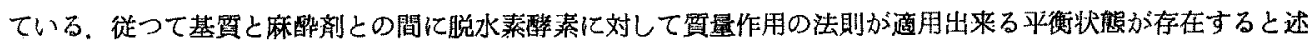

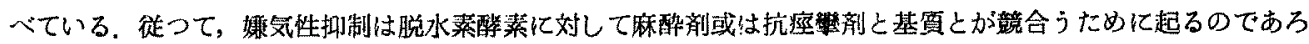

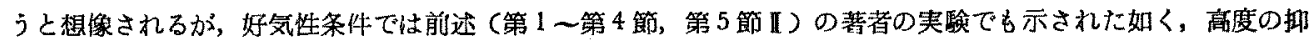

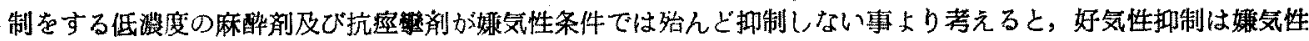

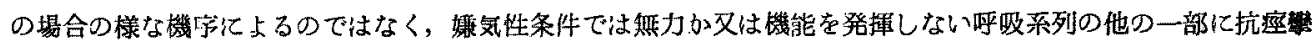

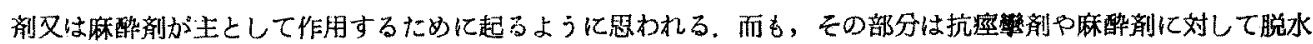

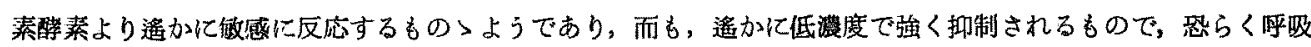

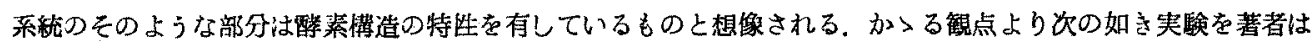
行つた.

第 6 簀 Cytochrome c, Cytochrome-oxidase に対するMA，AL 及びBAの影措

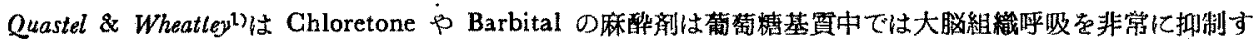
るような浱度で $p$-Phenylendiamin や挀珀酸を基筫とした時の呼吸を僅か抑制するか, 或は全然抑制しない事を

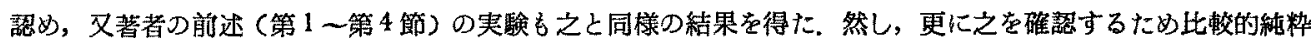
な酳素赀品に就て次の実驗を行つた。.

Gytochrome c は牛心上り Keilin \& Hartree 氏法 (1937) ${ }^{37)}$ に作り, Cytochrome-oxidase は豚心上り Keilin \& Hartree 氏法 (1938) ${ }^{38}$ 亿て作つた.

容器内容液 3.3cc，主室には $4 \times 10^{-2} \mathrm{M}-\mathrm{p}$-Phenylendiamin 含据 Ringer 氏液，側室には $0.05 \mathrm{cc} の$ Cytochrome-oxidase, 0.1ccの Cytochrome c，他方の側室にはMA，AL及びBAを夫々入れ，副室には10\% KOH を

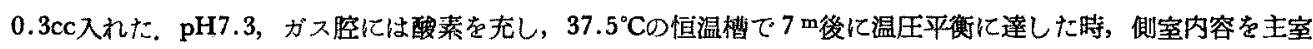
中に入れし，15简の酸素消費量をみた。

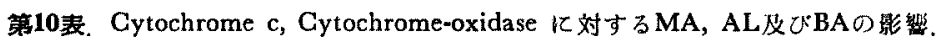

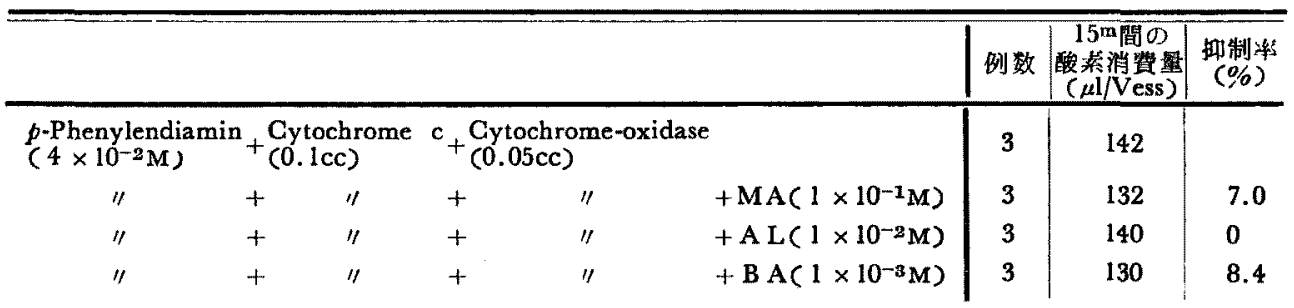

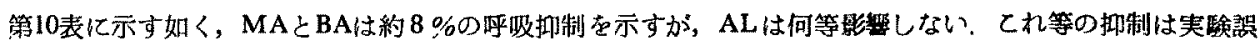
差筑囲であるから，MA，AL及びBAは Cytochrome c 及び Cytochrome-oxidase には影整しない椂に思われる。

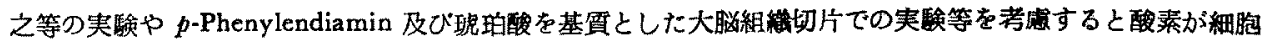

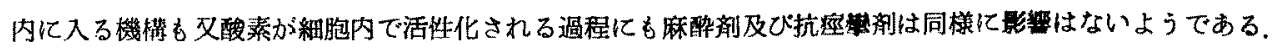

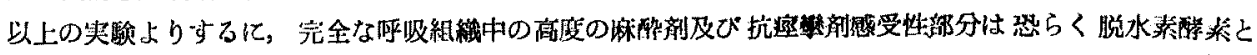




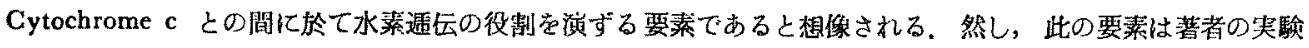

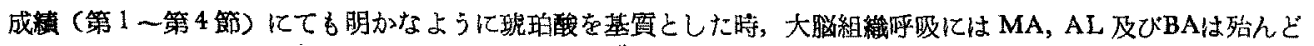

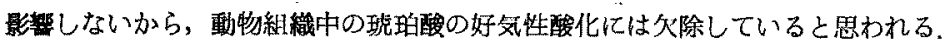

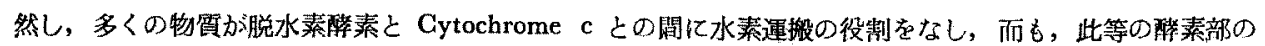

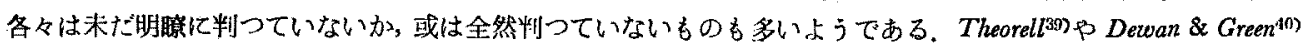
の研究によると Flavoprotein が呼吸系の此の部分に重要な役制を演し，而も，此の Flavoprotein (Diaphorase) は還元 DPN で遗元され，更に還元された Flavoprotein は Cytochrome 系の成分と反応する事が示され，又，

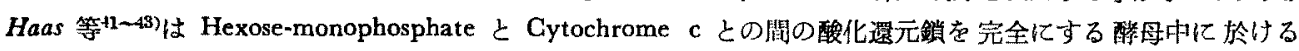
Flavoprotein の存在を報告している，従つて，著者は更に次の実驗足進めた。

\section{第 7 简 Diaphorase に対するMA，AL及びBAの影留}

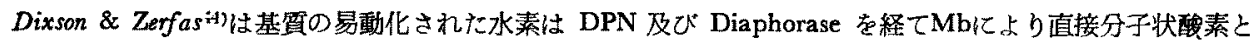
結合する事を証明しているから，此の方法を用いて実験した。

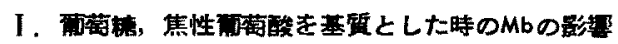

$\mathrm{Mb}$ は元来殺菌，消毒剂として用いられるものである，従つて泿度の

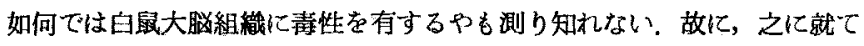
先ず予俑実験をした。

第11表に示す如く，大脳組織切恀与 呼吸に $\mathrm{Mb}$ は $5 \times 10^{-6_{M}} \sim 2 \times$

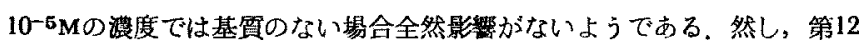

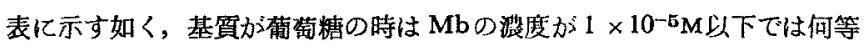

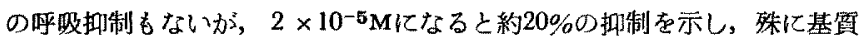

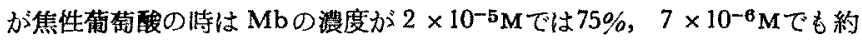

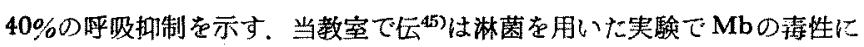

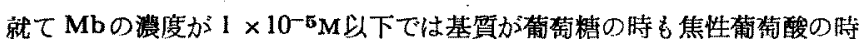

策11表，然基質に於ける白鼠 大脳組穖呼忣に及は す Mbの影響.

\begin{tabular}{c|c|c}
\hline \hline Mbの最終瀆苳 & 例数 & Qo.. \\
\hline $5 \times 10^{-6} \mathrm{M}$ & 3 & 3.4 \\
$7 \times 10^{-6} \mathrm{M}$ & 3 & 3.4 \\
$1 \times 10^{-5} \mathrm{M}$ & 3 & 3.4 \\
$2 \times 10^{-5} \mathrm{M}$ & 3 & 3.4 \\
- & 3 & 3.4
\end{tabular}

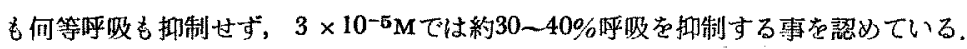

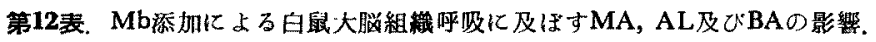

\begin{tabular}{|c|c|c|c|c|c|c|c|c|c|c|c|c|c|c|}
\hline & \multirow[b]{2}{*}{ Mb終彗㨦 } & \multicolumn{2}{|r|}{ 対 } & \multicolumn{2}{|l|}{ 照 } & \multicolumn{3}{|c|}{$\left(\begin{array}{c}\mathrm{MA} \\
\left(1 \times 10^{-1} \mathrm{M}\right)\end{array}\right.$} & \multicolumn{3}{|c|}{$\left(\begin{array}{c}\mathrm{AL}^{\mathrm{L}} \\
\left(1 \times 10^{-2} \mathrm{M}\right)\end{array}\right.$} & \multicolumn{3}{|c|}{$\left(\begin{array}{c}\mathbf{B} \bar{A} \\
\left(1 \times 10^{-3} \mathbf{M}\right)\end{array}\right.$} \\
\hline & & 例数 & $\frac{\mathrm{Qo}_{2}}{(\mathrm{Mb}-)}$ & $\begin{array}{c}\mathrm{Qo}_{2} \\
(\mathrm{Mb}+)\end{array}$ & 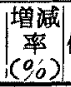 & 例数 & $\begin{array}{c}\mathrm{QO}^{2} \\
(\mathrm{Mb}+)\end{array}$ & 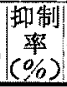 & 例数 & $\begin{array}{c}\mathrm{Qo}^{2} \\
\mathrm{Mb}+\end{array}$ & $\begin{array}{c}\text { 抑制 } \\
(\%) \\
(\%)\end{array}$ & 例数 & {$\left[\begin{array}{c}\mathrm{Qo}^{2} \\
(\mathrm{Mb}+-)\end{array}\right.$} & $\begin{array}{l}\text { 㧮制 } \\
\text { 率 } \\
(\%)\end{array}$ \\
\hline \multirow{3}{*}{$\begin{array}{l}\text { 葡街栯 } \\
(0.02 \mathrm{M})\end{array}$} & $7 \times 10^{-6} \mathrm{M}$ & 7 & 13.8 & 13.8 & 0 & 7 & 13.1 & 5 & 7 & 13.6 & 1 & 7 & 12.9 & 6 \\
\hline & $1 \times 10^{-5} \mathrm{M}$ & 3 & 14.3 & 14.3 & 0 & 3 & 13.1 & 8 & 3 & 15.4 & -18 & 3 & 13.0 & 9 \\
\hline & $2 \times 10^{-5} \mathrm{M}$ & 3 & 13.9 & 11.1 & -20 & 3 & 9.3 & 16 & 3 & 13.3 & -20 & 3 & 9.0 & 19 \\
\hline \multirow{3}{*}{$\begin{array}{l}\text { 焦性載陽酸 } \\
(0.02 \mathrm{M})\end{array}$} & $7 \times 10^{-6} \mathrm{M}$ & 5 & 11.3 & 7.1 & -37 & 5 & 7.1 & 0 & 5 & 8.6 & -21 & 5 & 7.1 & 0 \\
\hline & $1 \times 10^{-5} \mathrm{M}$ & 3 & 11.4 & 6.1 & -46 & 3 & 6.3 & -3 & 3 & 7.9 & -30 & 3 & 6.1 & 0 \\
\hline & $2 \times 10^{-5} \mathrm{M}$ & 3 & 13.2 & 3.3 & -75 & 3 & 3.7 & -12 & 3 & 5.0 & -52 & 3 & 3.8 & -15 \\
\hline
\end{tabular}

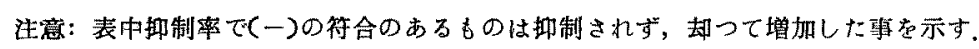

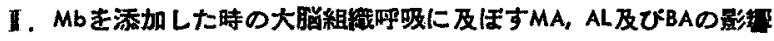

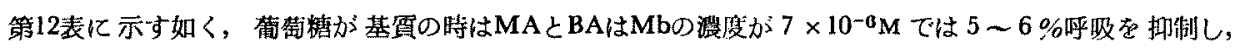

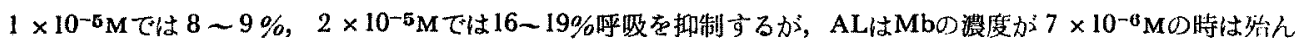

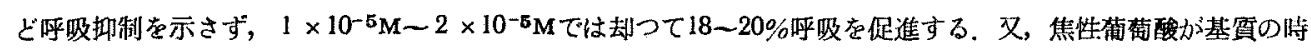

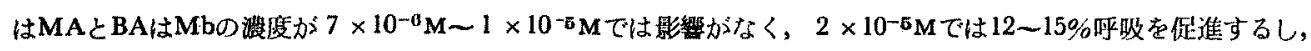

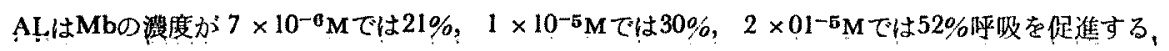




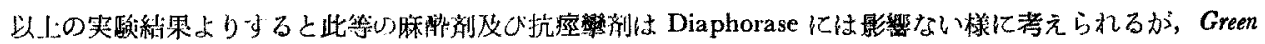

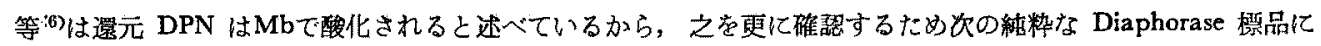
就て夷験した。

II. Diophorose に対するMA，AL及びBAの影泀

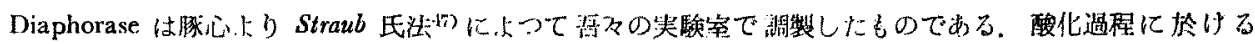

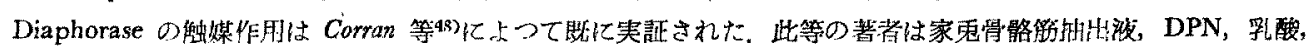

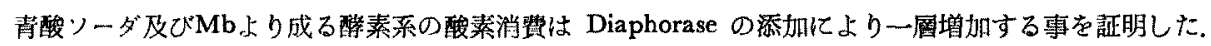

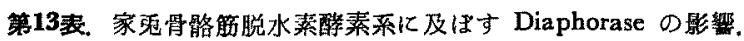

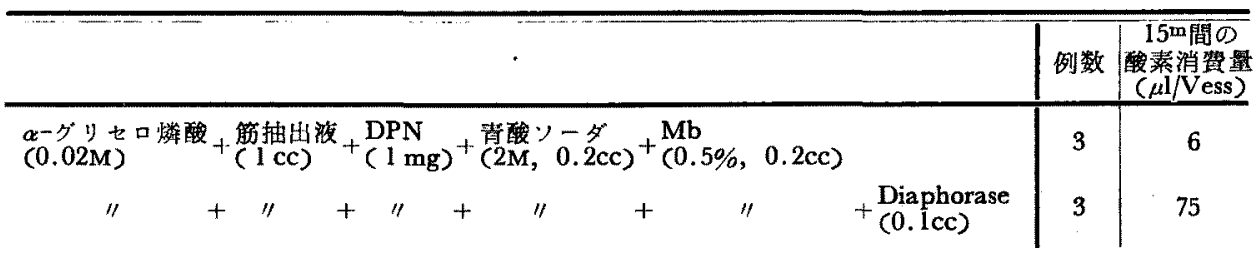

第13表に示す如く，Diaphorase を含まない醉素系は15m間の酸素消費量は $6 \mu 1$ であるが，Diaprorase を㧈 えると $75 \mu \mathrm{l}$ になる。此の方法を用いて炊の如く実験した。

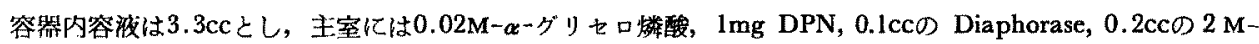

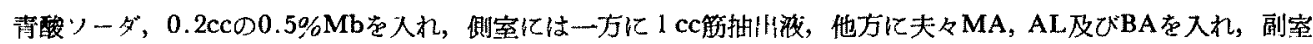

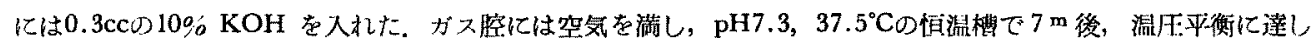

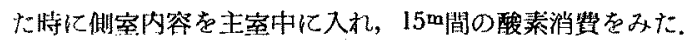

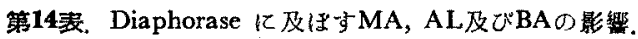

\begin{tabular}{|c|c|c|c|c|c|c|c|c|c|c|c|c|c|c|}
\hline \multirow[b]{2}{*}{ 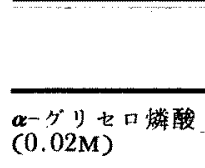 } & \multirow{2}{*}{\multicolumn{2}{|c|}{ 筋抽出液 }} & \multirow{2}{*}{\multicolumn{3}{|c|}{$+\frac{\mathrm{DPN}}{(1 \mathrm{mg})}$}} & \multirow{2}{*}{\multicolumn{2}{|c|}{$\begin{array}{l}\text { Diaph, rase } \\
(0.1 \mathrm{Cc})\end{array}$}} & \multirow{2}{*}{\multicolumn{2}{|c|}{${ }^{-1}(2 \mathrm{M}, 0.2 \mathrm{ccc})^{-1}$}} & \multirow{2}{*}{\multicolumn{2}{|c|}{$\begin{array}{l}\mathrm{Mb} \\
(0.5 \%, 0.2 \mathrm{cc})\end{array}$}} & \multirow{2}{*}{$\frac{\text { 例数 }}{3}$} & \multicolumn{2}{|c|}{ 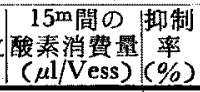 } \\
\hline & & & & & & & & & & & & & 75 & \\
\hline "I & 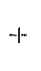 & "I & 1 & " & -1. & " & + & "I & +1 & $" 1$ & ${ }^{-1} \mathrm{MA}$ & 3 & 71 & 6 \\
\hline '" & 1 & $" 1$ & 1 & $" \prime$ & +1 & 11 & 1 & "I & 1 & $" 1$ & $+\begin{array}{l}\mathrm{AL} \\
\left(1 \times 10^{-2} \mathrm{M}\right)\end{array}$ & 3 & 74 & 2 \\
\hline$\prime \prime$ & + & $" 1$ & + & " & $\dashv$ & "I & + & "I & + & $" 1$ & $\begin{array}{l}+\mathbf{B} \\
\left(1 \times 10^{-3} \mathbf{M}\right)\end{array}$ & 3 & 69 & 8 \\
\hline
\end{tabular}

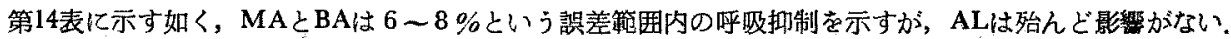

以上I，【，山の成縝よりするとDPNによる Diaphorase の還元も，又還元 Diaphorase のMbによる酸

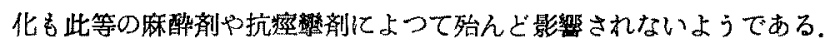

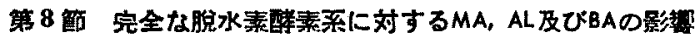

Michaelis \& Quastel ${ }^{23)}$ は Keilin \& Hartree 氏法38)により調製せる Cytochrome-oxidase 中には Flavoprotein や Cytochrome が含まれると云い，之に筋抽计液及び DPN を加えると完全な脱水素醉素系克作り酸絷を消費

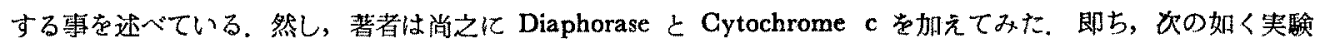
した.

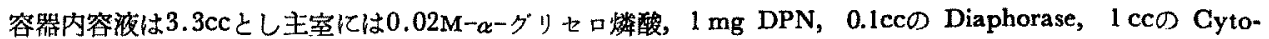

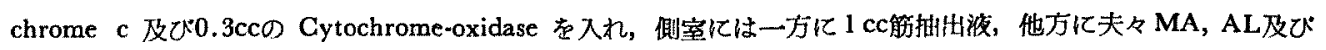

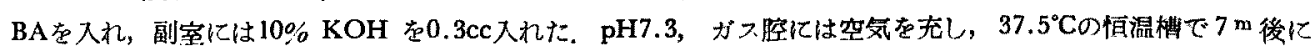

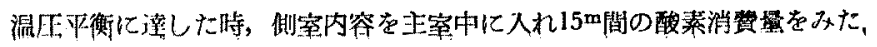




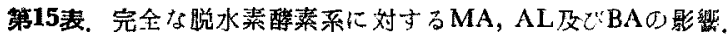

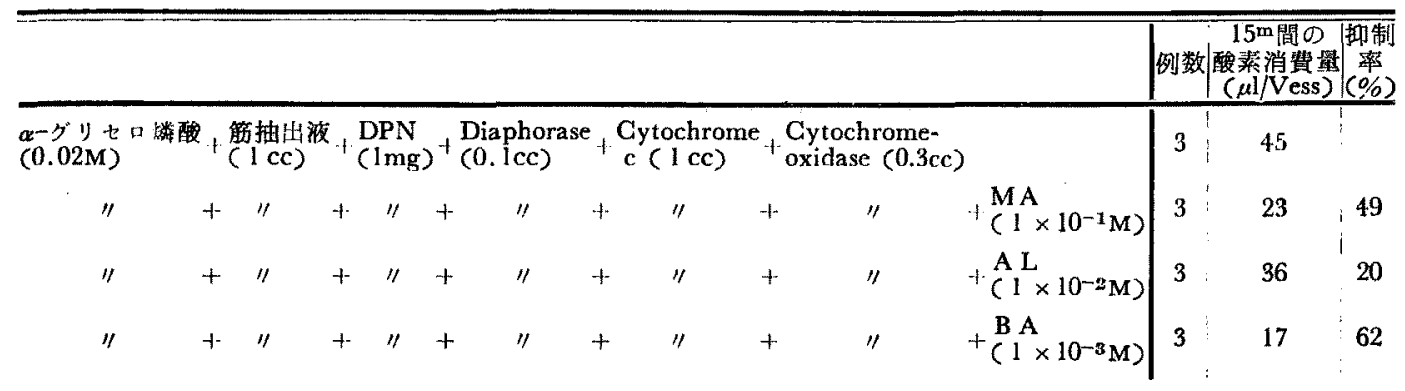

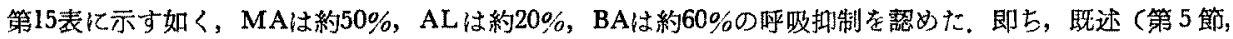

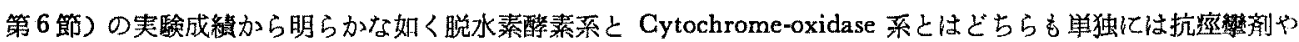

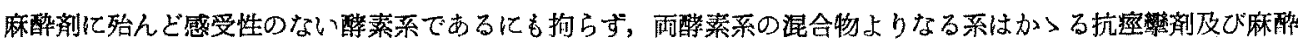
剂に高度の惎受性を示す.

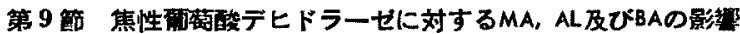

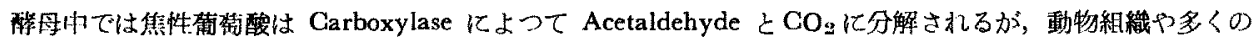

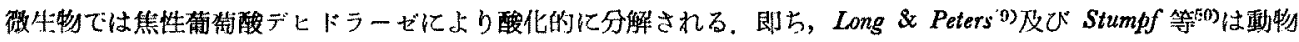

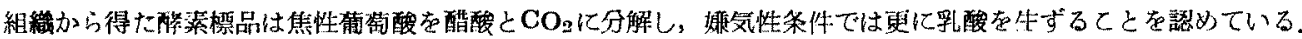
最近 Korkes 等51)によつて此の反沈は詳細飞された。，即ち，次の如くであり， $\mathrm{CH}_{3} \mathrm{COCOOH}+\mathrm{DPN}+\mathrm{CoA} \rightarrow$

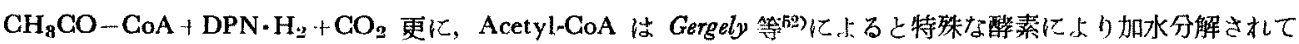
醋酸とCoAともなる。

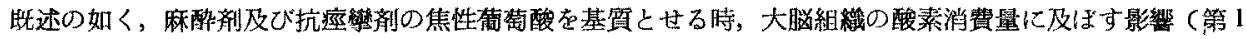

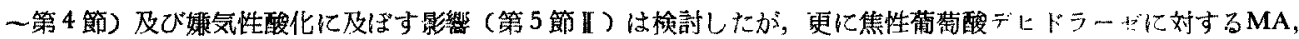

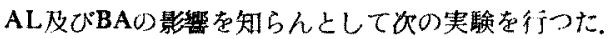

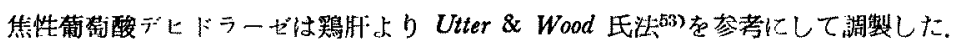

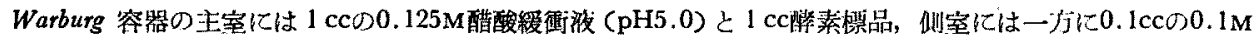

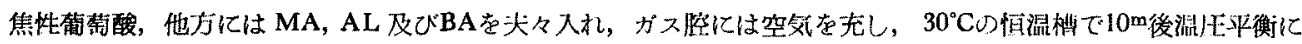

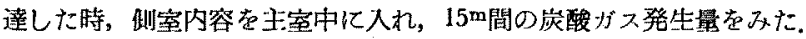

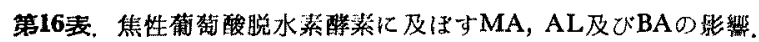

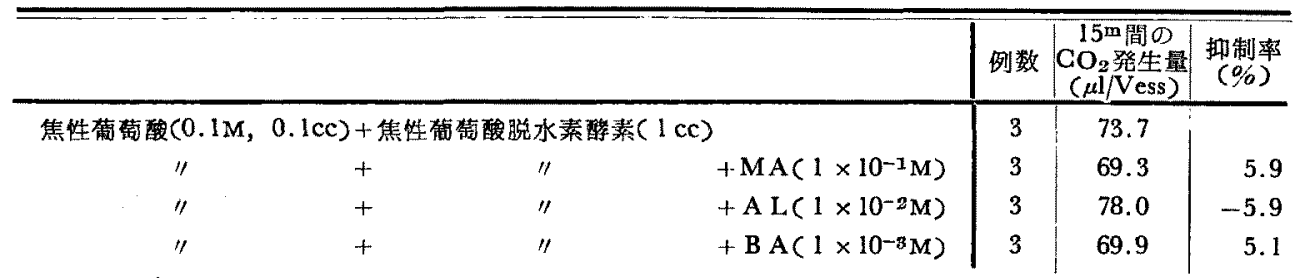

注意：表中抑制率てく一つ符合のあるものは㧕制きれず，却つて增加した事を示す。

第16表に示す如く，MAとBAは約 $6 \%$ 炭酸カス発生を抑制するが，ALは却つて約6\%え進さすのみで大し た影諳はないようである。

\section{第4章考按}

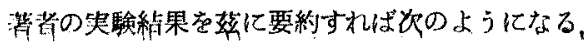




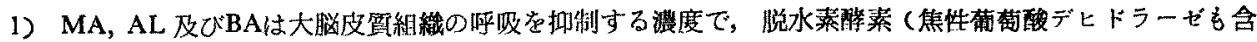
めて)，DPN 並びに Diaphorase に殆んど作用しない。

2) Cytochrome c 及び Cytochrome-oxidase にも殆んど作用しない.

3) 脱水素酵素, DPN, Diaphorase と Cytochrome c, Cytochrome-oxidase との混合物上り成る醉素系に 刘しては高度の呼吸抑制をする。

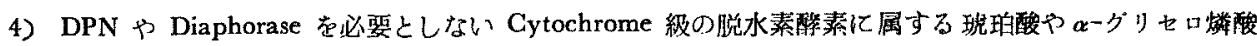

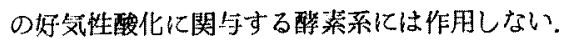

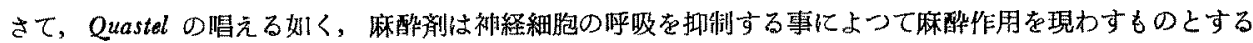

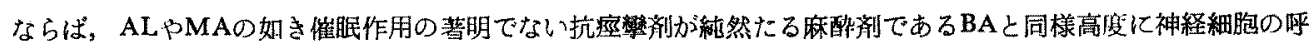

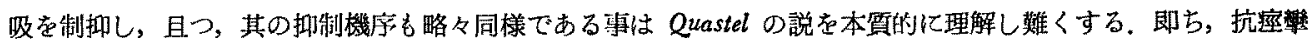

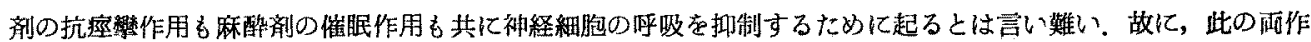
用は別個のもの〉ように思考される。

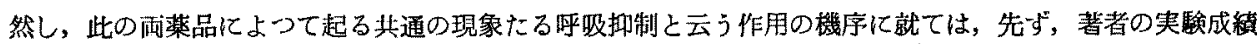
上りすれば，Flavoprotein (Diaphorase) と Cytochrome a, b, c の一つ或はをれと上の成分との間に麻酔詴及

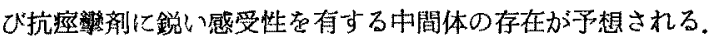

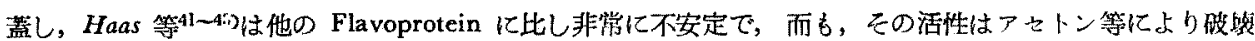
され易い特殊な Flavoprotein である Cytochrome c 還元搼秦の存在克主㖘している.

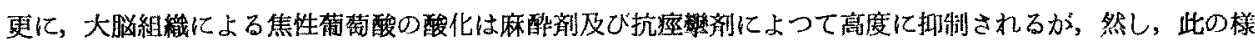
な酸化醉素は DPN の作用によらず Lipmann の仾究

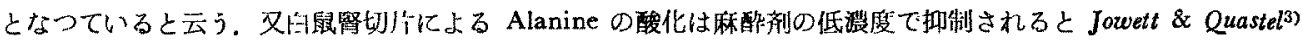

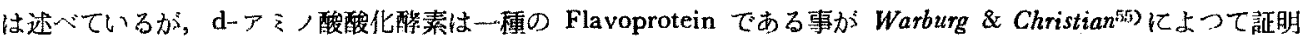
されている。

以上の如く，特殊な未知の Flavoprotein が還元 DPN と Gytochrome 系との間の水素運搬に重要な役制

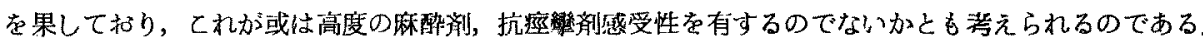

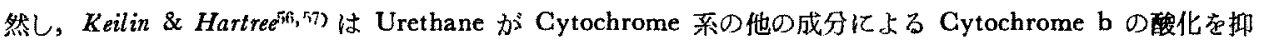

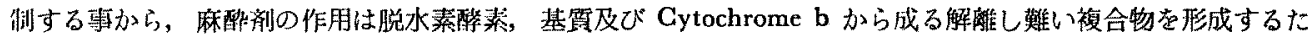

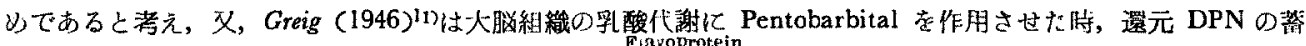

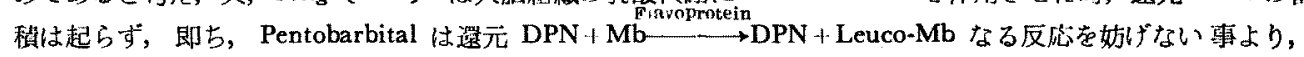

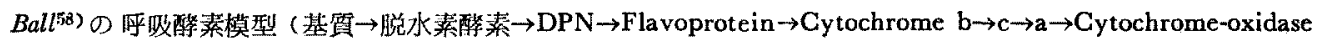

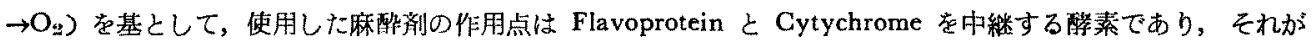
Cytochrome b 加或は他の酵素であつても，兔に角，Cytochrome b に似た酸化遥元電位をもつている酸素だと

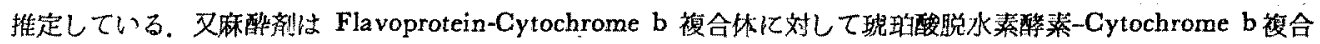

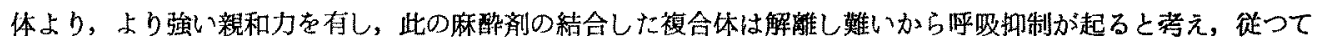

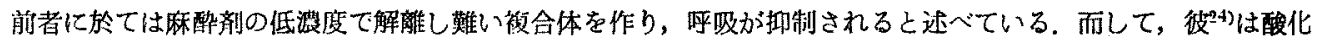

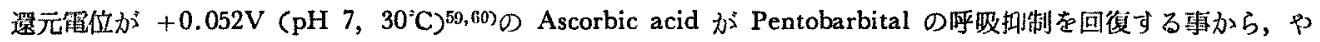

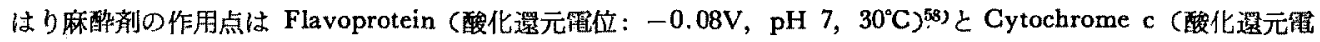

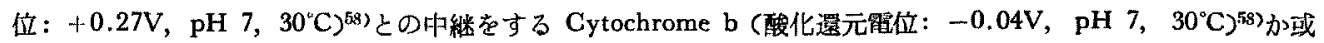
は此に近い酸化還元霄位をもつ酵素であると推定した。

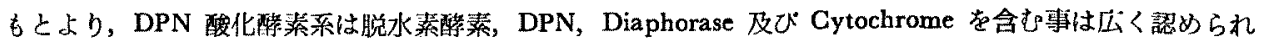
ているが，Cytochrome 系自体に関する成召に就ては一致した見解がない，斯くの如き Diaphorase とCytochrome-oxidase との間の反応機棈に関する不碓定は 細胞呼吸に関する現今の知識に実に重大な欠陷を与えてい るようである。即ち, Dewan \& Green ${ }^{40,61)}$ は Cytochrome a とbが必要であるが, 明確にc仙必要でないと迟

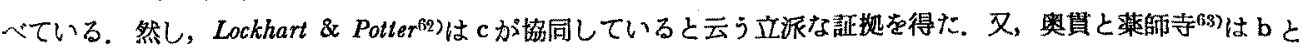

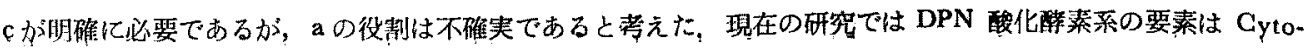




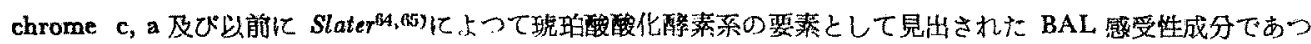

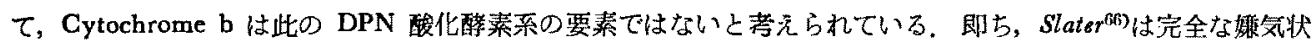

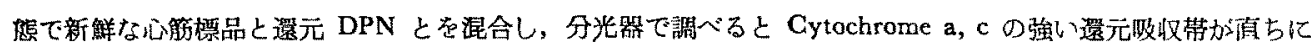

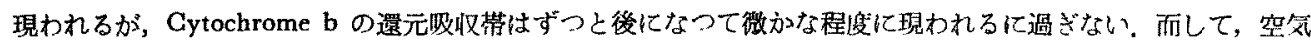

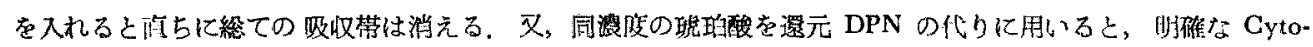

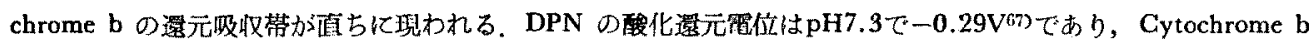
のそれよりも遙かに小であるから，単に熱力学的理的からでは Cytochrome b は使用された源度の還元 DPN

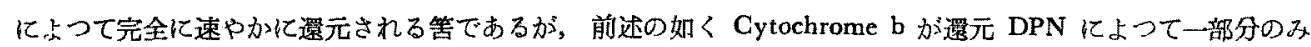

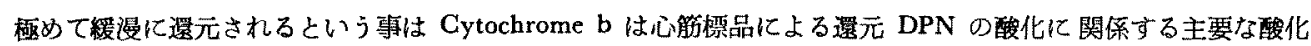

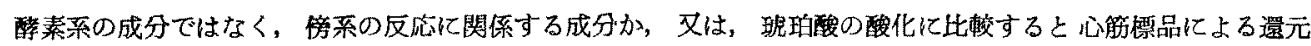
DPN の酸化は非常に緩漫であるかである，然し，此の点を追及した䀒々な雪験結果よりすると後者の理由は完 全に否定された。.

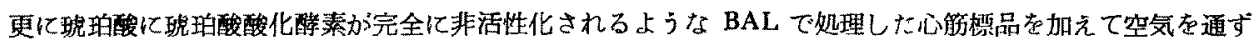
ると, 強い Cytochrome b の還元吸収带が現われるが

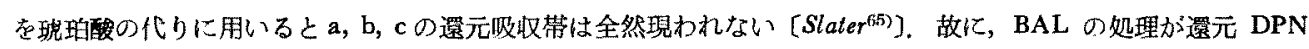

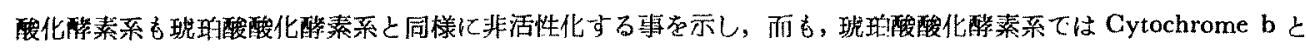

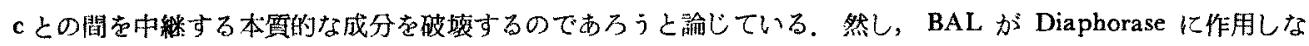

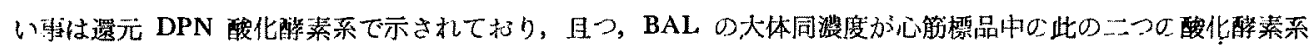

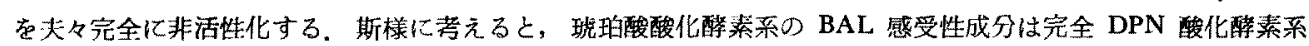

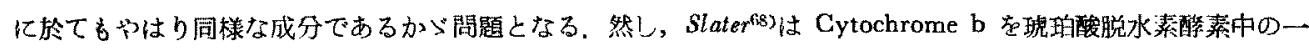
成分であると見做しているようである. 此の証扰は動物組織では総て陰性であるが, Pappenheimer \& Hendee"9は

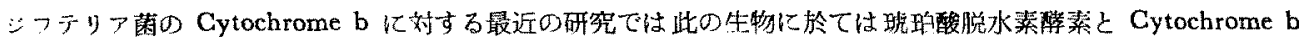
とは命一していると先張している。

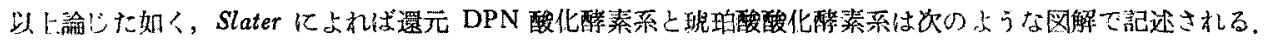

還元 DPN $\rightarrow$ Diaphorase

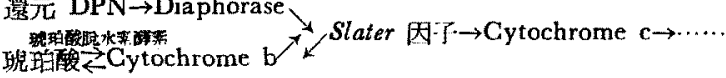

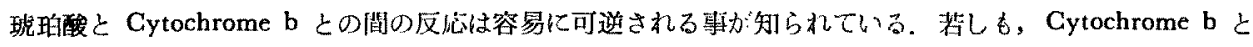

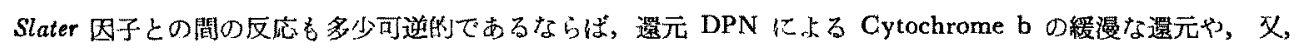
遥元 DPN $\rightarrow$ Diaphorase $\rightarrow$ Slater 因子 $\rightarrow$ Cytochrome $b \rightarrow フ マ ー ル$ 酸なる反応式によると思われるフマール酸の存 在下の還元 DPN の㵵気性酸化が理解される。

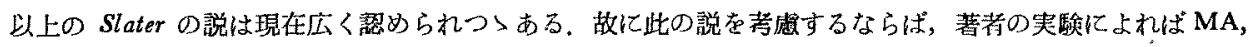

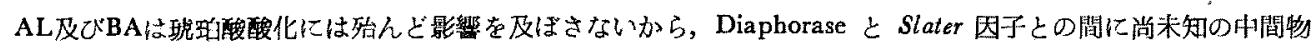

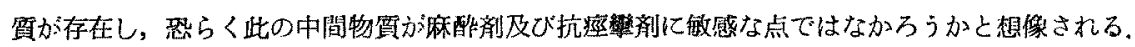

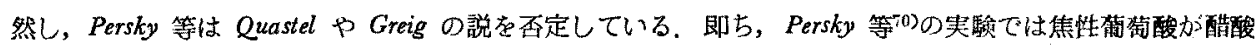

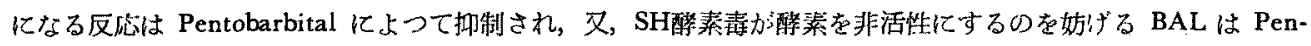

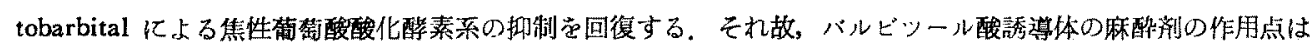

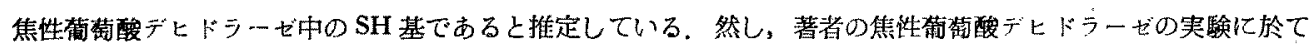

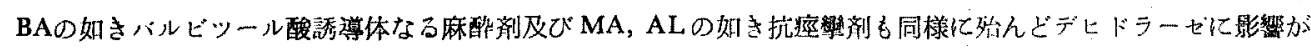
なかつたから，此の説は肖定出来ない.

\section{第 5 章 結語}

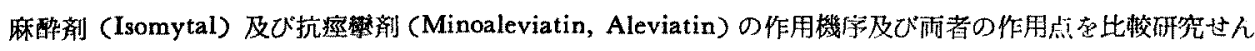

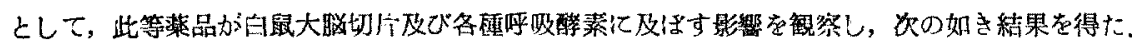

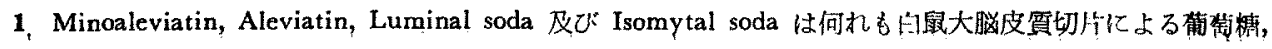




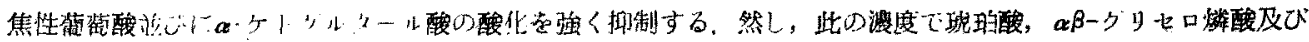
$p$-Phenylendiamin D酸化は㱠んど抑制しない。

2. 白鼠大范切片では构彞酸は利用されないようである。

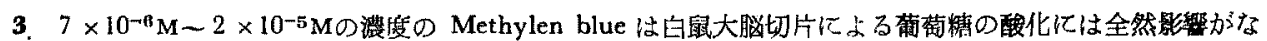
いか，或は，少し抑制するが，焦性载萄酸の酸化は30〜70\%抑制与る。.

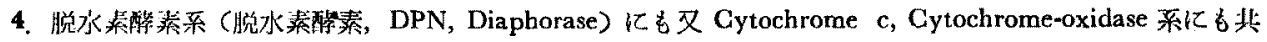
に Minoaleviatin, Aleviatin 及び Isomytal soda 仗多んど作用しない.

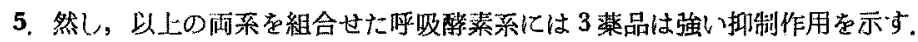

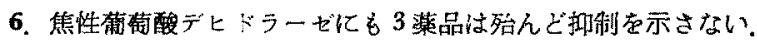

7. 以上の結果より，Minoaleviatin, Aleviatin 及び Isomytal soda は Diaphorase と Slater 因子との間の

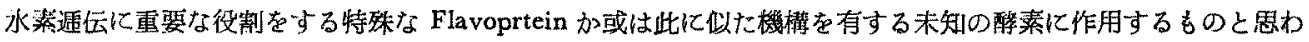
れる.

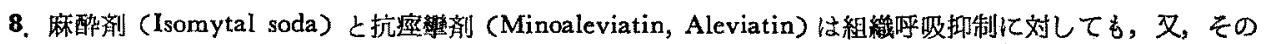

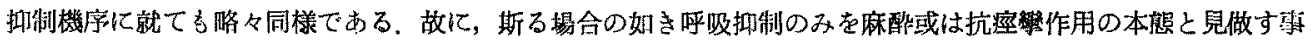
は中来ない.

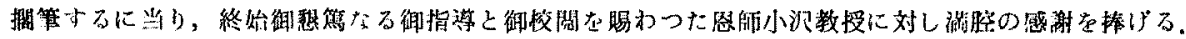

\section{引用娄}

1) Quastel, J.H. \& Wheatley, A.H.M.: Proc. Roy. Soc. London 1128, 60 (1932),

2) 同氏s: Biochem. J. 28, 1521 (1934).

3) Jowett, M. \& Quastel, J.H.: 同誌 31, 565 (1937).

4) 同氏ら：同缐 31, 1101 (1937).

5) Jowett, M.: J. Physiol. 92, 322 (1938).

6) Quastel, J.H.: Physiol. Rev. 19, 135 (1939).

7) Fuhrman, F.A. \& Field, J.: J. Pharmacol. 77, 392 (1943).

8) Wilkins, D.S. et al. : J. Lab. \& clin. Med. 35, 411 (1950).

9) Hundhausen, G.: Z. ges. exper. Med. 102, 477 (1938).

10) Himwich, H.E. et al.: Am. J. Physiol. 132, 293 (1941).

11) Greig, M.E. : J. Pharmacol. 87, 185 (1946).

12) Wilkins, D.S. et al.: J. Lab. \& clin. Med. 34, 846 (1949).

13) Schneler, F.W. \& Gross, E.G.: J. Pharmacol. 98, 28 (1950).

14) Wilkins, D.S. et al. : 同誌 98, 36 (1950).

15) Eiler, J.J. \& McEven, W.K. : Arch. Biochem. 20, 163 (1949).

16) Wortis. S.B. : Arch. Neurol. \& Psychiat. 33, 1022 (1935).

17) Westfall, B.A.: J. Pharmacol. 96, 193 (1949).

18) Fuhrman, F.A. \& Field, J.: Proc. Soc. Exper. Biol. \& Med. 49, 374 (1942).

19) 同氏ら: J. Pharmacol. 77, 229 (1943).

20) Brody, T.M. \& Bain, J.A. : Proc. Soc. Exper. Biol. \& Med. 77, 50 (1951).

21) 同氏 $5:$ J. Pharmacol. 110, 148 (1954).

22) Kozazea, S. et al. : Jap. J. Pharmacol. 3, 50 (1953).

23) Michaelis, M. \& Quastel, J.H.: Biochem. J. 35, 518 (1941).

24) Greig, M.E.: J. Pharmacol. 91, 317 (1947).

25）滕旧秋治：検任法とその底用，2版 (1949)， 
26) Umbreit, W.W. et al. : Manometric techiniques and tissue metabolism 6 Ed. (1951).

27) 同氏 5 : 同書 5 Ed. (1945).

28) Banga, I., Ochoa, S. \& Peters, R.A.: Biochem. J. 33, 1980 (1939).

29) Taplor, J.D. et al. : J. Pharmacol. 98, 392 (1949).

30) Wortis, S.B.: Trans. Am. Neurol. Assoc. 79, 1 (1940).

31) Quastel, J.H. \& Wheatley, A.H.M. : Biochem. J. 32, 936 (1938).

32) Green, D.E. et al. : 同誌 31, 2327 (1937).

33) Green, D.E.: 同譩 30, 629 (1936).

34) Euler, H.V. et al. : Hoppe-Seylers Z. 245, 218 (1936).

35) Williamson, S. \& Green, D.E. : J. biol. Chem. 135, 345 (1940).

36) Davies, D.R. \& Quastel, J.H.: Biochem. J. 26, 1672 (1932).

37) Keilin, D. \& Hartree, E.F.: Proc. Roy. Soc. London 122B, 293 (1937).

38) 同氏ら：同誌 1259,171 (1938).

39) Theorell, H.: Biochem. Z. 288, 317 (1936).

40) Dewan, J.G. \& Green, D.E.: Biochem. J. 32, 626 (1938).

41) Haas, E. et al.: Biochem. Z. 291, 79 (1937).

42) 同氏 $5: J$. biol. Chem. 136, 775 (1940).

43) 同氏放: 同誌 130, 425 (1939).

44) Dixson, M. \& Zerfas, L.G. : Biochem. J. 34, 371 (1940).

45) 伀于秋: 京都府医大誌 49, 5 (1951).

46) Green, D.E. et al. : Biochem. J. 30, 1489 (1936).

47) Straub, F.B.: 同夁 33, 787 (1939).

48) Corran, H.S. et al. : 同珿 33, 793 (1939).

49) Long, C. \& Peters: 同誌 33, 759 (1939).

50) Stumpf, P.K. et al. : J. biol. Chem. 167, 817 (1947).

51) Korkes, $S$. et al. : 同誌 193, 721 (1951).

52) Gergely, $J$. et al. : 同誌 198, 323 (1952).

53) Utter, M.F. \& Wood, H.G.: 同誌 164, 455 (1946).

54) Lipmann, F.: Nature, London 143, 436 (1939).

55) Warburg, O. \& Christian, W. : Biochem. Z. 298, 150 (1938).

56) Keilin, D. \& Hartree, E.F.: Proc. Roy. Soc. London 127B, 167 (1939).

57) 同氏5: 同誌 1298, 277 (1940).

58) Ball, E.G. : Ann. N.Y. Acad. Sc. 45, 363 (1944).

59) 同氏 $5:$ J. biol. Chem. 118, 219 (1937).

60) Green, D.E. : Biochem. J. 27, 1044 (1933).

61) Dewan, J.G. \& Green, D.E. : Nature, London 140, 1097 (1937).

62) Lockhart, E.E. \& Potter, V.R.: J. biol. Chem. 137, 1 (1941).

63) Okunuki, K. \& Yakushiji, E.: Proc. Imp. Acad. Japan 16, 144 (1940).

64) Slater, E.C.: Nature, London 161, 405 (1948).

65) 同氏: Biochem. J. 45, 14 (1949).

66) 同氏: 同諉 46, 499 (1950).

67) Borsook, H.: J. biol. Chem. 138, 629 (1950).

68) Slater, E.C.: Biochem. J. 45, 1 (1949).

69) Pappenheimer, A.M. \& Hendee, E.D. : J. biol. Chem. 180, 597 (1949),

70) Persky, H. et al. : J. Pharmacol. 100, 273 (1950), 